\title{
ALTERATION OF THE CHEMICAL COMPOSITION OF HUMAN IMMUNOGLOBULIN G BY STREPTOCOCCUS PYOGENES
}

\author{
Rawle M. McIntosh*, Claudius Kulvinskas and Donald B. Kaufman \\ The Gwynne Hazen Cherry Memorial Laboratories, Department of Pediatrics, \\ UCLA Medical Center, Los Angeles, California 90024, USA
}

IN previous communications (Barnett et al., 1970; McIntosh et al., 1970) we have suggested that nephritogenic streptococci may alter the chemical composition and immunogenicity of immunoglobulin G (IgG) in some patients by enzymatic action or by combination of streptococcal products with IgG. The following study was designed to test this hypothesis in vitro.

\section{MATERIALS AND METHODS}

Streptococcus pyogenes type 12, isolated from the pharynx of a patient with acute poststreptococcal glomerulonephritis, was subcultured in Todd-Hewitt broth and incubated at $37^{\circ} \mathrm{C}$ for $24 \mathrm{hr}$. The organisms were removed by centrifugation and washed with Dulbecco's solution, and serial dilutions were plated on blood-agar plates; $1 \mathrm{ml}$ of suspension containing $3 \times 10^{4}$ organisms was used for treatment of human IgG under different conditions.

Human IgG was precipitated from pooled human serum with 50 per cent. ammonium sulphate and purified by gel-filtration on Sephadex G 200 (Flodin and Killander, 1962) followed by chromatography on diethylaminoethyl (DEAE) cellulose (Tomasi and Kunkel, 1964). The IgG thus isolated was centrifuged at 15,000 r.p.m. and the supernatant fluid was tested for purity by immuno-electrophoresis and immunodiffusion in agar gel. The IgG was dialysed extensively against distilled water and was lyophilised. Eleven tests were set up.

Test I. $100 \mathrm{mg}$ of IgG was dissolved in $20 \mathrm{ml}$ of sterile Todd-Hewitt broth and centrifuged at 15,000 r.p.m. The supernatant fluid was centrifuged at 15,000 r.p.m. and passed through a Millipore filter; $3 \times 10^{4}$ organisms were added, and the mixture was incubated at $37^{\circ} \mathrm{C}$ for $24 \mathrm{hr}$.

Test II. The same procedure as in test I was performed, but incubation was at $4^{\circ} \mathrm{C}$.

Test III. $100 \mathrm{mg}$ of IgG was dissolved in sterile Todd-Hewitt broth as in test I, but no streptococci were added.

Test IV. Streptococci were added to $20 \mathrm{ml}$ of sterile Todd-Hewitt broth without IgG and the mixture was incubated at $37^{\circ} \mathrm{C}$.

Test $V$. The same procedure as in test IV was performed at $4^{\circ} \mathrm{C}$.

Tests VI, VII, VIII, IX, and $X$ were performed as tests I-V respectively, but Dulbecco's solution was used instead of Todd-Hewitt broth.

Test $X I$. Lyophilised untreated immunoglobulin without streptococci was incubated at $4^{\circ} \mathrm{C}$.

Tests I-X were run in duplicate. After incubation, the organisms were removed by repeated centrifugation. The final supernatant fluids were passed through Millipore filters and IgG was re-isolated from them by precipitation, gel filtration, and chromatography as before. No IgG was precipitated from tests IV, V, IX, or X. The IgG was dialysed extensively against distilled water and lyophilised.

Chemical analysis. Amino-acid analysis was performed on a Beckman amino-acid analyser by the method of Spackman, Stein and Moore (1958); hexose was estimated by the orcinol method (Weimer and Moshin, 1953), sialic acid by Svennerholm's method (1957), galactose by galactostat (Worthington Biochemicals, Inc., Freehold, New Jersey), and fucose by the method of Dische and Shettles (1948).

\section{Received 19 Nov. 1970; accepted 23 Mar. 1971.}

* Present address: Dept of Pediatrics, College of Physicians and Surgeons of Columbia University, 630 W. 168th St., New York, N.Y. 10032, USA. 
All analyses were performed in triplicate and the standard deviation was calculated.

Immunological studies. Immunodiffusion in agar gel was performed with goat antihuman immunoglobulin, Fab and Fc fragments (Hyland Laboratories), against normal human IgG and IgG from tests I-III, VI, VIII, and XI. Attempts to detect streptococcal antigens were made with antistreptococcal antisera by haemagglutination inhibition, immunodiffusion, and complement fixation (McIntosh et al.).

\section{RESULTS}

There were no differences in the amino-acid composition of IgG isolated in any of the tests. The results of other chemical studies are shown in the table. The presence of streptococci in the solution was associated with significant alterations in the content of hexose, sialic acid, galactose, and fucose. The changes were more marked after incubation at $37^{\circ} \mathrm{C}$ than at $4^{\circ} \mathrm{C}$ and also greater in Todd-Hewitt broth than in Dulbecco's solution.

TABLE

Chemical composition of $\mathrm{Ig} G$ treated by different methods

\begin{tabular}{|c|c|c|c|c|c|c|c|}
\hline \multirow{2}{*}{$\begin{array}{l}\text { Test } \\
\text { no. }\end{array}$} & \multirow{2}{*}{ Medium } & \multirow{2}{*}{$\begin{array}{l}\text { Incubation } \\
\text { temperature }\end{array}$} & \multirow{2}{*}{ Inoculum } & \multicolumn{4}{|c|}{$\begin{array}{l}\text { Content* (per cent.) in treated } \\
\text { immunoglobulin } \dagger, \text { of }\end{array}$} \\
\hline & & & & hexose & $\begin{array}{l}\text { sialic } \\
\text { acid }\end{array}$ & fucose & galactose \\
\hline $\begin{array}{l}\text { I } \\
\text { II } \\
\text { III } \\
\text { VI } \\
\text { VII } \\
\text { VIII } \\
\text { XI }\end{array}$ & $\begin{array}{l}\text { Todd-Hewitt } \\
\text { Todd-Hewitt } \\
\text { Todd-Hewitt } \\
\text { Dulbecco } \\
\text { Dulbecco } \\
\text { Dulbecco } \\
\text { Dulbecco }\end{array}$ & $\begin{array}{r}37^{\circ} \mathrm{C} \\
4^{\circ} \mathrm{C} \\
37^{\circ} \mathrm{C} \\
37^{\circ} \mathrm{C} \\
4^{\circ} \mathrm{C} \\
37^{\circ} \mathrm{C} \\
4^{\circ} \mathrm{C}\end{array}$ & $\begin{array}{c}\text { Streptococcus } \\
\text { Streptococcus } \\
\text { None } \\
\text { Streptococcus } \\
\text { Streptococcus } \\
\text { None } \\
\text { None }\end{array}$ & $\begin{array}{l}0.49 \\
0.51 \\
1.01 \\
0 \cdot 57 \\
0.60 \\
1.06 \\
1.08\end{array}$ & $\begin{array}{l}0 \cdot 11 \\
0 \cdot 15 \\
0 \cdot 28 \\
0 \cdot 11 \\
0 \cdot 15 \\
0 \cdot 24 \\
0 \cdot 34\end{array}$ & $\begin{array}{l}0 \cdot 04 \\
0 \cdot 06 \\
0 \cdot 21 \\
0 \cdot 05 \\
0 \cdot 06 \\
0 \cdot 20 \\
0 \cdot 20\end{array}$ & $\begin{array}{l}0 \cdot 69 \\
\ldots \\
0 \cdot 36 \\
0 \cdot 68 \\
\ldots .39 \\
0 \cdot 40\end{array}$ \\
\hline
\end{tabular}

* Mean of two tests.

$\dagger$ Standard deviation for: hexose \pm 0.03 per cent.; sialic acid $\pm \mathbf{0 . 0 3}$ per cent.; galactose \pm 0.06 per cent.; fucose \pm 0.01 per cent.

Careful examination of the table shows that the alterations cannot be attributed to hydrolysis by temperature or to the media.

Immunodiffusion studies showed precipitin lines of identity between normal IgG and IgG recovered from the tests. Streptococci and streptococcal proteins were not detected in the treated IgG.

\section{Discussion}

Microbial agents have often been associated with immunological diseases in man and laboratory animals (Dodge et al., 1968; Williams, 1968). The pathogenic mechanisms by which these agents produce disease is clear in some diseases, controversial in some, and not fully elucidated in others. In some diseases microbial agents or microbial products and their specific antibodies form immune complexes that damage glomerular basement-membranes (Oldstone and Dixon, 1969; Kaufman and McIntosh, 1971). In others there is doubt as to whether the micro-organism alters host tissue or serum protein, giving rise to an autoimmune or autologous immune disease (Lambert and Dixon, 1968), or whether reactivity between a microbial agent and tissue protein is the pathogenic mechanism (Markowitz, Armstrong and Kushner, 1960; Rapaport et al., 1969).

In post-streptococcal glomerulonephritis all these mechanisms have been postulated (Markowitz et al.; Lindberg, Vosti and Raffel, 1967; Lange et al., 1969; Rapaport et al.). We have suggested (McIntosh et al.) that the streptococcus alters IgG either by a simple 
mechanism or by interaction of the immunoglobulin with a protein from the organism, as, e.g., between gamma-globulins and protein A from Staphylococcus aureus.

This study suggests that, in vitro, streptococci alter the chemical composition of IgG. The mechanism is not clear, but the findings lead to speculation that altered immunoglobulin may be immunogenic, leading to the formation of pathogenic complexes with immunoglobulins. Another hypothesis is that this altered immunoglobulin possesses the biological properties of antigen-antibody complexes and leads to a "pseudo" immune-complex disease.

We are now working with other organisms including non-nephritogenic streptococci and with bacterial and viral enzymes to study the effects of these on chemistry and immunogenicity of IgG.

\section{SUMMARY}

Incubation with Streptococcus pyogenes type 12 was shown to lead to marked alterations of the fucose, galactose, and total hexose content of human immunoglobulin G (IgG). Immunological studies showed at least partial identity of this altered IgG and normal IgG. Streptococcal antigen was not found in the altered immunoglobulin. We suggest that if such alterations occurred in vivo, the altered immunoglobulin might become autoimmunogenic or might possess the biological properties of immune complexes and thus be of immunopathological significance in post-streptococcal glomerulonephritis.

This work was supported by USPHS grants 1-501-FR 05354, A1 09420-01 ALY, and HD0060.

\section{REFERENCES}

Barnett, E. V., Bluestone, R., Cracchiolo, A., Goldberg, L. S., Kantor, G. L., AND McIntosh, R. M. 1970. Cryoglobulinemia and disease. Ann. Intern. Med., 73, 95.

Dische, Z., AND Shetrles, L. B. 1948. A specific color reaction of methylpentoses and a spectrophotometric micromethod for their determination. J. Biol. Chem., 175, 595.

Dodge, W. F., Spargo, B. H., Bass, J. A., AND Travis, L. B. 1968. The relationship between the clinical and pathologic features of poststreptococcal glomerulonephritis. A study of the early natural history. Medicine, Baltimore, 47, 227.

Flodin, P., AND Killander, J. 1962. Fractionation of human-serum proteins by gel filtration. Biochim. biophys. Acta, 63, 403.

Kaufman, D. B., AND MCINTOSH, R. M. 1971. The pathogenesis of the renal lesion in a patient with streptococcal disease, infected ventriculoatrial shunt, cryoglobulinemia and nephritis. Amer. J. Med., 50, 262.

LAMBert, P. H., AND Dixon, F. J. 1968. Pathogenesis of the glomerulonephritis of NZB/W mice. J. Exp. Med., 127, 507.

Lange, K., Semar, M., Ty, Antonia, AND Treser, G. 1969. A specific antigen and antibody in acute post-streptococcal glomerulonephritis. Clin. Res., 17, 468.

LINDBERG, LoIS H., VosTI, K. L., AND RAFFEL, S. 1967. Experimental streptococcal glomerulonephritis in rats. J. Immun., 99, 1231.

McIntosh, R. M., Kaufman, D. B., Kulvinskas, C., and Grossman, B. J. 1970. Cryoglobulins I. Studies on the nature, incidence and clinical significance of serum cryoproteins in glomerulonephritis. J. Lab. Clin. Med., 75, 566.

Markowitz, A. S., Armstrong, S. H., JR, AND Kushner, D. S. 1960. Immunological relationships between the rat glomerulus and nephritogenic streptococci. Nature, Lond., 187, 1095.

OldSTONE, M. B. A., AND DiXon, F. J. 1969. Pathogenesis of chronic disease associated with persistent lymphocytic choriomeningitis viral infection. I. Relationship of antibody production to disease in neonatally infected mice. J. Exp. Med., 129, 483.

Rapaport, F. T., Markowitz, A. S., McCluskey, R. T., Hanaoka, T., and Shimada, T. 1969. Induction of renal disease with antisera to group A streptococcal membranes. Transplantn Proc., 1, 981. 
Spackman, D. H., Stein, W. H., AND Moore, S. 1958. Automatic recording apparatus for use in chromatography of amino acids. Analyt. Chem., 30, 1190.

SVENNERHOLM, L. 1957. Quantitative estimation of sialic acids. II. A colorimetric resorcinol-hydrochloric acid method. Biochim. biophys. Acta, 24, 604.

TOMASI, T., AND KUNKEL, H. G. 1964. Isolation of 7S and 19S gamma globulins. In Methods in medical research, ed. by H. N. Eisen, Chicago, vol. 10, p. 80.

WeIMER, H. E., AND Moshin, JEAN R. 1953. Serum glycoprotein concentrations in experimental tuberculosis of guinea pigs. Amer. Rev. Tuberc., 68, 594.

Williams, R. C., JR 1968. Immune deposit diseases of mink and mice. Possible analogies to the connective tissue disorders. Arthritis Rheum., 11, 593. 